\title{
Refractory Diffuse Large B-Cell Lymphoma Germinal Center B-Cell Type
}

National Cancer Institute

\section{Source}

National Cancer Institute. Refractory Diffuse Large B-Cell Lymphoma Germinal Center B-

Cell Type. NCl Thesaurus. Code C160238.

Diffuse large B-cell lymphoma germinal center B-cell type that is resistant to treatment. 